The Israeli Journal of Aquaculture - Bamidgeh, IJA_69.2017.1424, 9 pages

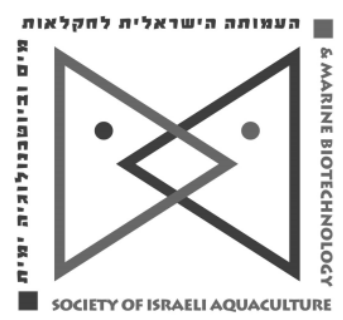

The IJA appears exclusively as a peer-reviewed on-line open-access journal at http://www.siamb.org.il. To read papers free of charge, please register online at registration form.

Sale of $I J A$ papers is strictly forbidden.

\title{
Dietary Protein Requirement of Juvenile Ide, Leuciscus idus in Relation to Growth Performance, Whole-body Composition and Plasma Parameters
}

\author{
Mingchun Ren ${ }^{1}{ }^{2}$, Ke $\mathrm{Ji}^{2}$, Hualiang Liang ${ }^{2}$, Xianping $\mathrm{Ge}^{1,2 *}$,
} Haifeng $\mathrm{Mi}^{1}$, 3*

\author{
${ }^{1}$ Key Laboratory of Freshwater Fisheries and Germplasm Resources \\ Utilization, Ministry of Agriculture, Freshwater Fisheries Research Center, \\ Chinese Academy of Fishery Sciences, Wuxi 214081, China \\ ${ }^{2}$ Wuxi Fisheries College, Nanjing Agricultural University, Wuxi 214081 \\ China \\ ${ }^{3}$ Aquaculture Research Institute, Tongwei group, Chendu 610041, PR
}

\section{China}

Keywords: Ide Leuciscus idus; Protein; Growth performance; Whole-body composition

\begin{abstract}
A 60-day feeding trial was conducted to determine the dietary protein requirements of juvenile ide, Leuciscus idus. Six iso-energetic experimental diets were formulated to contain graded protein levels ranging from $26.5 \%$ to $50.9 \%$ of dry diet. At the end of feeding trial, final weight (FW), weight gain (WG), and specific growth rate (SGR) increased significantly with increasing dietary protein levels up to $36.4 \%$, and thereafter decreased with further increase of dietary protein levels $(P<0.05)$. Feed conversion ratio (FCR) showed a converse trend $(P<0.05)$. Hepatosomatic index and viscerosomatic index were negatively related to dietary protein levels $(P<0.05)$. Increase of dietary protein levels significantly improved whole-body protein content and decreased lipid content $(P<0.05)$. White blood cell counts, red blood cell, hemoglobin, and hematocrit, were independent of dietary protein levels $(P>0.05)$. Plasma protein content was not significantly affected by dietary protein levels $(P>0.05)$, while plasma triglyceride and glucose concentrations were decreased significantly with increasing dietary protein levels $(P<0.05)$. The highest aspartic transaminase activity was observed in fish fed diet $26.5 \%$ protein, and the lowest value was observed in $36.4 \%$ protein group $(P<0.05)$. Based on SGR and $\mathrm{FCR}$, the dietary protein requirement of juvenile ide was determined to be $36.9 \%-37.7 \%$ of dry diet. Dietary methionine and lysine levels for optimal growth was calculated to be $0.83 \%$ and $2.25 \%$ of dry diet, respectively.
\end{abstract}

* Corresponding author. Xianping Ge, E-mail: gexp@ffrc.cn;

Haifeng Mi, E-mail: mihf@tongwei.com 


\section{Introduction}

The ide (Leuciscus idus) is a freshwater fish species of the family Cyprinidae which is distributed across northern Europe and Asia (Rohtla et al., 2015). This fish species is an important natural component of the aquatic ecosystem, and is popular in sport fishing (Błachuta, 1998). Aquaculture of this species began with the success of artificial propagation. Ide is considered one of the most promising cultured fish species in China because of its rapid growth, and high market price. However, information about its nutritional requirements is limited. Formulated feed production of ide relies on formulae for grass carp Ctenopharyngodon Idella, or common carp Cyprinus carpio. Basic nutritional research is needed to find optimal feeds for this species.

Protein is an essential component in fish diets and plays an important role in supplying energy and amino acids for fish growth. It is the most expensive compound in fish diets, and excess dietary protein levels results in high nitrogen emission into ambient waters, which in turn affects feed intake and fish growth (Webb and Gatlin, 2003; Mohanta et al., 2007; Zehra and Khan, 2012). The protein requirement corresponding to essential amino acids (EAA) profile is generally the first nutritional parameter to be determined for a cultured fish species, and this information provides the basis for formulation of commercial diets when little knowledge is available on EAA, lipid, and other nutrient requirements for this fish species (NRC, 2011).

To the best of our knowledge, there are no available studies concerning dietary protein requirements for ide. Thus, the aim of the present study was to investigate the effects of dietary protein levels on growth, whole-body composition, and plasma parameters of juvenile ide, and to determine the optimum dietary protein level for this species with semi-purified diets.

\section{Materials and methods}

Diet preparation. Formulation of the experimental diets are presented in Table 1. Six isoenergetic diets were formulated to contain graded levels of protein $(26.5 \%, 31.5 \%$, $36.4 \%, 41.2 \%, 46.0 \%$ and $50.9 \%$ of dry weight, respectively) using fish meal, casein and gelatin as protein sources, and fish oil as the lipid source. These protein levels were chosen based on the results of the protein requirements of other Cyprinidae species (Deng et al, 2013; NRC, 2011). The ratio of casein and gelatin was 4:1 to provide a balanced dietary amino acid profile (Deng et al., 2011). Corn starch levels were adjusted accordingly to make the diets iso-energetic. All the ingredients were ground into powder and thoroughly mixed with fish oil and water, then forced though a pelletizer (4-2 style, Xinchang machinery LTD, China) and dried in a ventilated oven at $30^{\circ} \mathrm{C}$. After drying, all diets were sealed in bags and stored at $-15^{\circ} \mathrm{C}$ until further use.

Experimental procedure. Fish husbandry was conducted in an indoor re-circulating freshwater system consisting of 18 fiberglass tanks (300L) with equal supplemental aeration (Wuxi, China). Juvenile ide were obtained from a commercial farm (Tianjin, China). Prior to the feeding trial, the fish were fed a commercial diet (35\% crude protein and $5 \%$ crude lipid) for 2 weeks to acclimate to the experimental conditions. After fasting for $24 \mathrm{~h}$, juvenile fish (initial weight $33 \mathrm{~g}$ ) were randomly sorted into eighteen tanks with 15 fish per tank. Each diet was randomly assigned to triplicate tanks. Fish were hand-fed three times daily at 8:00,12:00, and 16:00, until apparent satiation, on the basis of visual observation, 7 days a week. During the 60 day feeding trail, water quality parameters were kept as follows: temperature was constant $\left(24 \pm 1^{\circ} \mathrm{C}\right)$, pH was $7.0-7.5$, ammonia nitrogen was lower than $0.05 \mathrm{mg} / \mathrm{L}$, and dissolved oxygen was not less than $6.0 \mathrm{mg} / \mathrm{L}$. Photoperiod was natural (light-dark cycle) throughout the experiment. No mortality was observed in all dietary treatments during the 60 day feeding trial. 
Table 1. Formulation and proximate composition of the experimental diets (\% dry matter)

\begin{tabular}{|c|c|c|c|c|c|c|}
\hline \multirow{2}{*}{ Ingredients } & \multicolumn{6}{|c|}{ Diet Number } \\
\hline & 1 & 2 & 3 & 4 & 5 & 6 \\
\hline Fish meal $^{1}$ & 19.0 & 19.0 & 19.0 & 19.0 & 19.0 & 19.0 \\
\hline Casein $^{1}$ & 12.0 & 16.5 & 21.0 & 25.5 & 30.0 & 34.5 \\
\hline Gelatin $^{1}$ & 3.00 & 4.13 & 5.25 & 6.38 & 7.50 & 8.63 \\
\hline Fish oil & 2.00 & 2.00 & 2.00 & 2.00 & 2.00 & 2.00 \\
\hline Soybean lecithin & 2.50 & 2.50 & 2.50 & 2.50 & 2.50 & 2.50 \\
\hline Vitamin premix3 & 2.00 & 2.00 & 2.00 & 2.00 & 2.00 & 2.00 \\
\hline Mineral premix4 & 2.00 & 2.00 & 2.00 & 2.00 & 2.00 & 2.00 \\
\hline Corn starch & 40.0 & 33.5 & 27.0 & 20.5 & 14.0 & 7.50 \\
\hline Cellulose & 5.34 & 6.22 & 7.09 & 7.97 & 8.84 & 9.72 \\
\hline Carboxymethyl cellulose & 8.00 & 8.00 & 8.00 & 8.00 & 8.00 & 8.00 \\
\hline Ethoxyquin & 0.01 & 0.01 & 0.01 & 0.01 & 0.01 & 0.01 \\
\hline $\mathrm{Ca}\left(\mathrm{H}_{2} \mathrm{PO}_{4}\right)_{2}$ & 2.00 & 2.00 & 2.00 & 2.00 & 2.00 & 2.00 \\
\hline Bentonite & 2.00 & 2.00 & 2.00 & 2.00 & 2.00 & 2.00 \\
\hline Choline chloride & 0.10 & 0.10 & 0.10 & 0.10 & 0.10 & 0.10 \\
\hline Vitamin C & 0.05 & 0.05 & 0.05 & 0.05 & 0.05 & 0.05 \\
\hline \multicolumn{7}{|c|}{ Proximate analysis (\% of dry diet) } \\
\hline Crude protein & 26.5 & 31.5 & 36.4 & 41.2 & 46.0 & 50.9 \\
\hline Crude lipid & 6.30 & 6.20 & 6.24 & 6.24 & 6.25 & 6.31 \\
\hline Gross energy (KJ g-1)5 & 15.6 & 15.6 & 15.7 & 15.7 & 15.7 & 15.7 \\
\hline \multicolumn{7}{|l|}{ Essential amino acid } \\
\hline Arginine & 1.13 & 1.41 & 1.61 & 1.81 & 2.01 & 2.22 \\
\hline Histidine & 0.62 & 0.80 & 0.91 & 1.01 & 1.11 & 1.21 \\
\hline Isoleucine & 1.06 & 1.26 & 1.42 & 1.63 & 1.81 & 2.02 \\
\hline Leucine & 1.81 & 2.31 & 2.64 & 3.08 & 3.41 & 3.70 \\
\hline Lysine & 1.57 & 1.89 & 2.18 & 2.42 & 2.69 & 3.01 \\
\hline Methionine & 0.58 & 0.66 & 0.78 & 0.89 & 1.02 & 1.12 \\
\hline Phenylalanine & 1.06 & 1.23 & 1.45 & 1.65 & 1.85 & 2.03 \\
\hline Threonine & 0.81 & 1.06 & 1.23 & 1.42 & 1.51 & 1.73 \\
\hline Valine & 1.24 & 1.55 & 1.80 & 2.02 & 2.31 & 2.53 \\
\hline
\end{tabular}

${ }^{1}$ Casein, obtained from Hua'an Biological Products Lit. (Gansu, China), crude protein 90.0\%; gelatin, obtained from Zhanyun chemical Lit. (Shanghai, China), crude protein 90.3\%; fish meal, obtained from Copeinca (Lima, Peru), crude protein $68.4 \%$, crude lipid $10.3 \%$.

${ }^{2}$ Vitamins premix (IU or $\mathrm{mg} / \mathrm{kg}$ of diet): vitamin A, $25000 \mathrm{IU}$; vitamin D3, $20000 \mathrm{IU}$; vitamin E, $200 \mathrm{mg}$; vitamin K3, $20 \mathrm{mg}$; thiamin, $40 \mathrm{mg}$; riboflavin, $50 \mathrm{mg}$; calcium pantothenate, 100mg; pyridoxine $\mathrm{HCl}$, 40mg; cyanocobalamin, $0.2 \mathrm{mg}$; biotin, 6mg; folic acid, $20 \mathrm{mg}$; niacin, 200mg; inositol, 1000mg; Vitamin C, $2000 \mathrm{mg}$; Choline, $2000 \mathrm{mg}$ and cellulose was used as a carrier.

${ }^{3}$ Mineral premix ( $\mathrm{g} / \mathrm{kg}$ of diet): calcium biphosphate, $20 \mathrm{~g}$; sodium chloride, 2.6; potassium chloride, $5 \mathrm{~g}$; magnesium sulphate, $2 \mathrm{~g}$; ferrous sulphate, $0.9 \mathrm{~g}$; zinc sulphate, $0.06 \mathrm{~g}$; cupric sulphate, 0.02; manganese sulphate, $0.03 \mathrm{~g}$; sodium selenate, $0.02 \mathrm{~g}$; cobalt chloride, $0.05 \mathrm{~g}$; potassium iodide, 0.004 ; and zeolite was used as a carrier.

${ }^{4}$ Digestible energy calculated based on $23.6 \mathrm{~kJ} / \mathrm{g}$ for protein, $39.5 \mathrm{~kJ} / \mathrm{g}$ for lipid and $17.2 \mathrm{~kJ} / \mathrm{g}$ for starch (Ye et al., 2017).

Sample collection. At the end of the feeding trial, total numbers and mean body weight of fish in each tank were determined after fasting $24 \mathrm{~h}$. Five fish per tank were euthanized using MS-222 $(100 \mathrm{mg} / \mathrm{L})$, and then blood samples were collected immediately from the caudal vein using heparinized syringes. Following centrifugation $(3500 \times \mathrm{g}, 10$ min, $4^{\circ} \mathrm{C}$ ), the plasma was separated. All the samples were stored at $-80^{\circ} \mathrm{C}$ until analysis. Per cage, ten fish at the beginning, and five fish at the end of the experiment were sampled and stored at $-20^{\circ} \mathrm{C}$ for analysis of whole-body composition.

Laboratory analysis. Dry matter, crude protein, and lipid were determined according to the established methods of AOAC (2003): dry matter after drying in an oven at $105^{\circ} \mathrm{C}$ until constant weight; crude protein $(\mathrm{N} \times 6.25)$ by Kjeldahl method after acid digestion; lipid by ether extraction using Soxhlet. Amino acid concentrations were determined by a professional laboratory (Jiangnan University, Wuxi, China). Diets were freeze-dried overnight, and then hydrolyzed for 24 hours in $6 \mathrm{~N} \mathrm{HCl}$ at $110^{\circ} \mathrm{C}$. After pretreatment, all 
samples were analyzed with an Agilent-1100 amino acid determination system (Agilent Technologies Co., Ltd., Santa Clara, USA). Tryptophan could not be detected after acid hydrolysis.

Red blood cell (RBC) count, white blood cell (WBC), hemoglobin (HGB), and hematocrit (HCT) were measured using an Auto Hematology Analyzer (BC-5300Vet, Mindray, PR China) with a test kit from Shenzhen Mindray Medical International Co. Ltd., PR China. Aspartate aminotransferase (AST) activity was determined by a colorimetric test kit (Mindray Bio Medical Co., Ltd., Shenzhen, China) according to Reitman and Frankel (1957). Analyses of glucose, total protein, and total triglyceride levels in plasma were carried out with an automatic biochemical analyzer (Mindray BS-400, Mindray Medical International Ltd., Shenzhen, China) as in the previous description (Ren et al., 2015).

Statistical analysis. Data were transformed if necessary after evaluating assumptions of normality, equality of variances, and outliers, and subjected to one-way analysis of variance (ANOVA) using the software of the SPSS 13.0 for Windows. Significant differences in the means between dietary treatments were evaluated by Tukey's multiple range test. Mean differences were considered significant at a $P$ value equal or less than 0.05 . The second-order polynomial regression model (Zeitoun et al., 1976) was used to estimate the optimum dietary protein requirement for juvenile ide on the basis of SGR and FCR after comparing the estimation coefficient (R2) between broken-line regression model and second- order polynomial regression model.

\section{Results}

Growth performance. Results of growth performance of the juvenile ide are presented in Table 2. The lowest final weight (FW, 71.8g), weight gain (WG, 115.5\%), and specific growth rate (SGR, $1.28 \%$ /day) were observed in fish fed a diet which contained $26.5 \%$ protein $(P<0.05)$. FW, WG, and SGR values significantly increased with increasing dietary protein levels up to $36.4 \%$ of dry diet, and thereafter decreased $(P<0.05)$. Feed conversion ratio (FCR) presented a reverse trend $(P<0.05)$. Hepatosomatic index (HSI) and viscerosomatic index (VSI) decreased with the increasing dietary protein levels $(P<0.05)$.

Table 2. Growth performance of juvenile ide fed with the experimental diets

\begin{tabular}{llllllll}
\hline Protein & $I W(g)^{1}$ & $F W(g)^{2}$ & $W G(\%)^{3}$ & $S G R(\% / d a y)^{4}$ & $F C R(\%)^{5}$ & $H S I(\%)^{6}$ & $V S I(\%)^{7}$ \\
\hline 26.5 & $33.3 \pm 0.08$ & $71.8 \pm 0.81^{\mathrm{a}}$ & $115.5 \pm 2.30^{\mathrm{a}}$ & $1.28 \pm 0.02^{\mathrm{a}}$ & $2.36 \pm 0.03^{\mathrm{d}}$ & $2.09 \pm 0.12^{\mathrm{b}}$ & $9.82 \pm 0.91^{\mathrm{b}}$ \\
31.5 & $33.2 \pm 0.04$ & $77.6 \pm 0.70^{\mathrm{bc}}$ & $133.8 \pm 2.14^{\mathrm{bc}}$ & $1.42 \pm 0.02^{\mathrm{bc}}$ & $2.12 \pm 0.04^{\mathrm{ab}}$ & $2.00 \pm 0.11^{\mathrm{b}}$ & $9.65 \pm 0.27^{\mathrm{b}}$ \\
36.4 & $33.9 \pm 0.06$ & $79.3 \pm 0.84^{\mathrm{c}}$ & $137.5 \pm 2.59^{\mathrm{c}}$ & $1.44 \pm 0.02^{\mathrm{c}}$ & $2.04 \pm 0.04^{\mathrm{a}}$ & $1.89 \pm 0.06^{\mathrm{b}}$ & $9.53 \pm 0.29^{\mathrm{b}}$ \\
41.2 & $33.3 \pm 0.10$ & $76.9 \pm 0.96^{\mathrm{bc}}$ & $130.7 \pm 2.69^{\mathrm{bc}}$ & $1.39 \pm 0.02^{\mathrm{bc}}$ & $2.17 \pm 0.05^{\mathrm{ab}}$ & $1.79 \pm 0.18^{\mathrm{b}}$ & $8.37 \pm 0.40^{\mathrm{a}}$ \\
46.0 & $33.1 \pm 0.10$ & $73.6 \pm 0.77^{\mathrm{ab}}$ & $121.6 \pm 2.36^{\mathrm{ab}}$ & $1.33 \pm 0.03^{\mathrm{ab}}$ & $2.25 \pm 0.06^{\mathrm{bc}}$ & $1.71 \pm 0.12^{\mathrm{b}}$ & $8.21 \pm 0.45^{\mathrm{a}}$ \\
50.9 & $33.4 \pm 0.13$ & $73.1 \pm 0.77^{\mathrm{ab}}$ & $118.7 \pm 2.52^{\mathrm{ab}}$ & $1.31 \pm 0.03^{\mathrm{ab}}$ & $2.30 \pm 0.05^{\mathrm{cd}}$ & $1.32 \pm 0.13^{\mathrm{a}}$ & $7.62 \pm 0.26^{\mathrm{a}}$ \\
\hline
\end{tabular}

Mean values and standard error $(\mathrm{M} \pm \mathrm{SE})$ are presented for each parameter. Significant differences within the diets are indicated by different superscript letters $(P<0.05)$

${ }^{1}$ IW $(\mathrm{g})$ : initial weight.

${ }^{2} \mathrm{FW}(\mathrm{g})$ : final weigh.

${ }^{3}$ WG (\%): weight gain $=100 \times$ (final weight -initial weight) /initial weight.

${ }^{4}$ SGR (\%/day): specific growth rate $=100 \times(($ In FBW-In IBW $) /$ experimental days $)$.

${ }^{5}$ FCR $(\%)$ : feed conversion ratio $=100 \times$ dry feed intake $/$ wet weight gain .

${ }^{6} \mathrm{HSI}(\%)$ : hepatosomatic index $=100 \times$ (liver weight /body weight $)$.

${ }^{7}$ VSI $(\%)$ : viscerosomatic index $=100 \times$ (visceral weight/body weight).

Using the second-order polynomial regression model, the optimal dietary protein level for juvenile ide was estimated to be $36.9 \%$ of dry diet $\left(y=-0.0009 x^{2}+0.0665 x+\right.$ $0.1548, R^{2}=0.6555$, Fig.1) and $37.5 \%$ of dry diet $\left(y=0.0016 x^{2}-0.1205 x+4.3959\right.$, $\mathrm{R}^{2}=0.6141$, Fig. 2) on the basis of SGR and FCR, respectively. Based on SGR, dietary methionine and lysine level for optimal growth was $0.83 \%$ of dry diet

$\left(y=-1.7242 x^{2}+2.8632 x+0.2338, R^{2}=0.6094\right)$ and $2.25 \%$ of dry diet $\left(y=-0.2444 x^{2}\right.$ $\left.+1.1022 x+0.1738, R^{2}=0.6444\right)$, respectively. 


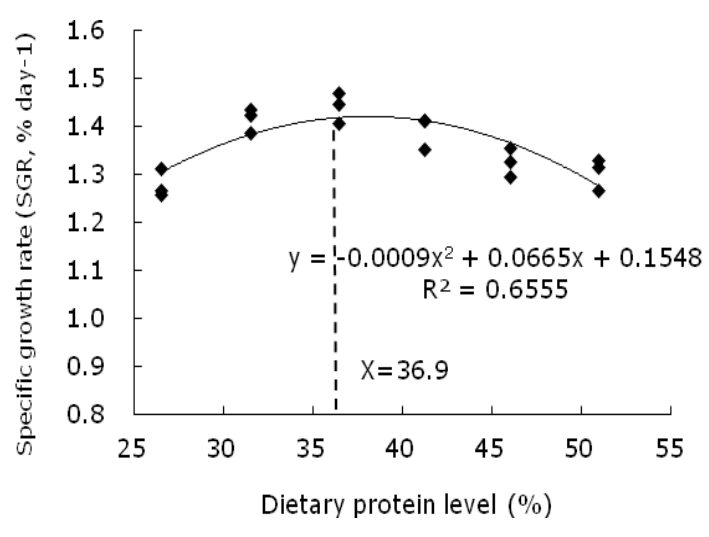

Figure 1. Protein requirement for juvenile ide Leuciscus idus calculated by secondorder polynomial regression analysis of specific growth rate (SGR) against dietary protein levels.

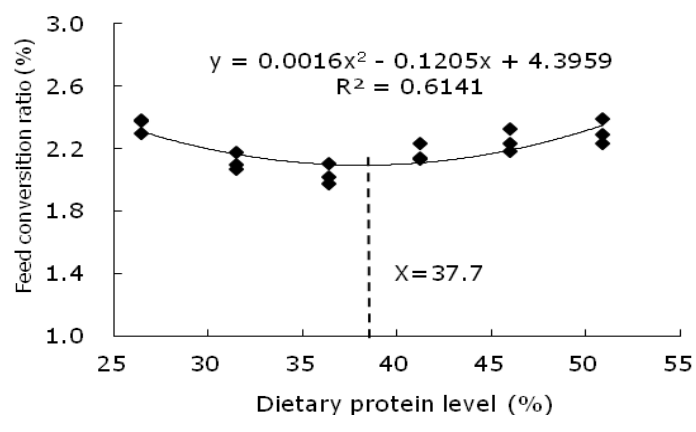

Figure 2. Protein requirement for juvenile ide Leuciscus idus calculated by secondorder polynomial regression analysis of feed conversion ratio (FCR) against dietary protein levels.

Whole-body composition. Whole-body composition is presented in Table 3. No significant differences were observed in whole-body moisture and ash content between the different dietary treatments $(P>0.05)$. Significantly lower whole-body protein content was observed in fish fed $26.5 \%$ protein diets compared to those fed diets with 36.4 $50.9 \%$ protein $(P<0.05)$. A decreasing trend of whole-body lipid was found in fish fed diets with increasing protein levels $(P<0.05)$.

Table 3. Whole-body composition (wet basis) of juvenile ide fed with the experimental diets

\begin{tabular}{lllll}
\hline Protein level (\%) & Moisture (\%) & Protein (\%) & Lipid (\%) & Ash (\%) \\
\hline 26.5 & $67.9 \pm 0.58$ & $17.1 \pm 0.09^{\mathrm{a}}$ & $12.5 \pm 0.31^{\mathrm{bc}}$ & $3.44 \pm 0.23$ \\
31.5 & $65.9 \pm 0.73$ & $17.8 \pm 0.19^{\mathrm{ab}}$ & $12.7 \pm 0.16^{\mathrm{c}}$ & $3.39 \pm 0.24$ \\
36.4 & $66.3 \pm 0.27$ & $18.3 \pm 0.23^{\mathrm{b}}$ & $11.6 \pm 0.16^{\mathrm{b}}$ & $3.53 \pm 0.26$ \\
41.2 & $66.8 \pm 0.13$ & $18.2 \pm 0.18^{\mathrm{b}}$ & $9.82 \pm 0.18^{\mathrm{a}}$ & $3.54 \pm 0.28$ \\
46.0 & $67.9 \pm 0.59$ & $18.2 \pm 0.18^{\mathrm{b}}$ & $9.60 \pm 0.33^{\mathrm{a}}$ & $3.48 \pm 0.25$ \\
50.9 & $67.6 \pm 0.44$ & $18.1 \pm 0.25^{\mathrm{b}}$ & $10.2 \pm 0.13^{\mathrm{a}}$ & $3.49 \pm 0.22$ \\
\hline
\end{tabular}

Mean values and standard error $(\mathrm{M} \pm \mathrm{SE})$ are presented for each parameter. Significant differences within the diets are indicated by different superscript letters $(P<0.05)$.

Hematological parameters. There were no significant differences $(P>0.05)$ in the hematological parameters including white blood cell (WBC), red blood cell (RBC), hemoglobin (HGB), and hematocrit (HCT) among the groups (Table 4).

Table 4. Blood hematological parameters of juvenile ide fed with the experimental diets

\begin{tabular}{lllll}
\hline Protein level $(\%)$ & $W B C\left(10^{9} / \mathrm{L}\right)$ & $R B C\left(10^{12} / \mathrm{L}\right)$ & $H G B(\mathrm{~g} / \mathrm{L})$ & $H C T(\%)$ \\
\hline 26.5 & $195.7 \pm 3.63$ & $1.65 \pm 0.05$ & $95.5 \pm 2.56$ & $25.7 \pm 1.19$ \\
31.5 & $202.5 \pm 5.53$ & $1.64 \pm 0.03$ & $98.6 \pm 3.45$ & $27.4 \pm 2.24$ \\
36.4 & $201.3 \pm 2.85$ & $1.66 \pm 0.03$ & $98.4 \pm 1.97$ & $26.5 \pm 1.65$ \\
41.2 & $207.0 \pm 8.10$ & $1.53 \pm 0.10$ & $92.5 \pm 3.48$ & $24.9 \pm 2.46$ \\
46.0 & $211.0 \pm 4.74$ & $1.68 \pm 0.06$ & $101.3 \pm 2.45$ & $26.9 \pm 2.51$ \\
50.9 & $200.9 \pm 5.02$ & $1.58 \pm 0.09$ & $93.7 \pm 3.52$ & $28.1 \pm 1.56$ \\
\hline
\end{tabular}

White blood cell (WBC), red blood cell (RBC), hemoglobin (HGB) and hematocrit (HCT). Mean values and standard error $(M \pm S E)$ are presented for each parameter. Significant differences within the diets are indicated by different letters $(P<0.05)$.

Plasma parameters. Results of plasma parameters are presented in Table 5. Plasma total protein content was not significantly affected by dietary protein levels $(P>0.05)$. The highest AST activity was observed in fish fed diet containing $26.5 \%$ protein and the lowest value was observed in fish fed diets with $36.4 \%$ protein $(P<0.05)$. A decreased 
trend was found in plasma glucose and total triglyceride content with the increasing dietary protein levels $(P<0.05)$.

Table 5 Plasma parameters of juvenile ide fed with the experimental diets

\begin{tabular}{lllll}
\hline Protein level $(\%)$ & $A S T(\mathrm{U} / \mathrm{L})$ & $T P(\mathrm{~g} / \mathrm{L})$ & $T G(\mathrm{mmol} / \mathrm{L})$ & Glucose $(\mathrm{mmol} / \mathrm{L})$ \\
\hline 26.5 & $591.8 \pm 49.06^{\mathrm{b}}$ & $37.6 \pm 1.75$ & $8.99 \pm 0.83^{\mathrm{b}}$ & $16.5 \pm 1.09^{\mathrm{b}}$ \\
31.5 & $567.0 \pm 41.62^{\mathrm{ab}}$ & $40.6 \pm 1.52$ & $8.53 \pm 0.52^{\mathrm{ab}}$ & $16.2 \pm 1.27^{\mathrm{ab}}$ \\
36.4 & $422.4 \pm 31.63^{\mathrm{a}}$ & $41.7 \pm 0.83$ & $7.57 \pm 0.66^{\mathrm{ab}}$ & $13.5 \pm 0.83^{\mathrm{ab}}$ \\
41.2 & $480.8 \pm 39.79^{\mathrm{ab}}$ & $39.6 \pm 1.67$ & $7.46 \pm 0.51^{\mathrm{ab}}$ & $12.7 \pm 1.22^{\mathrm{ab}}$ \\
46.0 & $440.3 \pm 27.11^{\mathrm{ab}}$ & $40.0 \pm 1.66$ & $7.61 \pm 0.35^{\mathrm{ab}}$ & $11.9 \pm 0.70^{\mathrm{a}}$ \\
50.9 & $497.6 \pm 34.49^{\mathrm{ab}}$ & $38.8 \pm 2.25$ & $6.91 \pm 0.61^{\mathrm{a}}$ & $12.4 \pm 0.99^{\mathrm{ab}}$ \\
\hline
\end{tabular}

Aspartate aminotransferase (AST), total protein (TP) and total triglyceride (TG).

Mean values and standard error $(M \pm S E)$ are presented for each parameter. Significant differences within the diets are indicated by different superscript letters $(P<0.05)$.

\section{Discussion}

In the present study, FW, WG, and SGR of juvenile ide were significantly affected by dietary protein levels. This has been well documented in scientific literature for other fish species (Parazo, 1990; Tibbetts et al., 2000; Yang et al., 2003; Kim and Lee, 2005; Kaushik and Seiliez, 2010). Feed conversion ratio of juvenile ide in the present study decreased in relation to increasing dietary protein levels; the lowest FCR was found in fish fed a diet with $36.4 \%$ protein, and thereafter showed an increasing trend. Similar results have been noted in other fish species, such as in olive flounder Paralichthys olivaceus (Kim et al., 2002), tiger puffer, Takifugu rubripes (Kim and Lee, 2009), and silver barb, Puntius gonionotus (Mohanta et al., 2008). The present study indicated that it is necessary to provide adequate dietary protein for the growth of juvenile ide. However, it is also important to avoid excessive dietary protein which inhibits growth and feed utilization, and increases the cost of diets for juvenile ide.

Dietary protein requirements for juvenile ide ranging between $33 \mathrm{~g}-80 \mathrm{~g}$ is estimated to be $36.9-37.7 \%$ of dry diet based on SGR and FCR in this study; this is in the range of dietary requirements for omnivorous fish species. The present result is slightly lower than that reported for common carp (38\%; NRC, 2011), gibel carp, Carassius Auratus Gibelio (40\%; Yun et al., 2015), barbless carp, Cyprinus pellegrini, (37.3-43.6\%), (Deng et al., 2013), and higher than the reports for silver barb (31.8\%; Mohanta et al., 2008). However, dietary protein requirements were influenced by dietary EAA profile. The protein requirement corresponds to the well-documented requirements for specific EAA, especially limiting EAA such as methionine and lysine (NRC, 2011). In this study, dietary EAA was well balanced by modifying the ratio of protein sources, and the dietary methionine and lysine level for optimal growth of juvenile ide was calculated to be $0.83 \%$ and $2.25 \%$ of dry diet, respectively, which is similar to common carp (methionine $0.8 \%$ of diet and lysine $2.2 \%$ of diet; Nose, 1979). The present result is the first quantitative nutrient requirement data reported for the ide. Establishment of dietary protein levels for optimal growth of juvenile ide contributes to the development of specific feeds for the developing fish.

In this study, the increase of dietary protein levels significantly reduced HSI and VSI levels of juvenile ide. Similar results have been found in haddock, Melanogrammus aeglfinus (Kim and Lall, 2001), and obscure puffer, Takifugu obscurus (Ye et al., 2017). In our study, our results were not unexpected as the dietary starch levels were reduced with increasing dietary protein levels in order to keep the experimental diets isoenergetic. It is accepted that increasing dietary carbohydrate improves glycogen levels in fish liver, and the increase of water associated with glycogen in the liver causes higher HSI (Bergot, 19790, while carbohydrates can be converted to lipids (Brauge et al., 1995) and deposited in viscerosomatic tissues of fish which might then lead to higher VSI value.

In the present study, dietary protein levels significantly affected whole-body composition of the ide. The lowest whole-body protein content was found in fish fed a diet with the lowest dietary protein level. Similar results have been reported for other fish species (Ahmad, 2008; Kim and Lee, 2009; Zhang et al., 2010). However, there are no further increases of whole-body protein when the dietary protein level exceeds $36.4 \%$, suggesting that excess that dietary protein is not used for body protein synthesis in juvenile ide. 
In this study, whole-body lipid content of juvenile ide decreased in relation to increasing dietary protein levels. This result agrees with reports of bagrid catfish Mystus nemurus ( $\mathrm{Ng}$ et al., 2001), yellow catfish Horabagrus brachysoma (Giri et al., 2006), Nile tilapia Oreochromis niloticus (Gaye-Siessegger et al., 2007), and obscure puffer (Ye et al., 2017). A possible explanation for this result in our study is that the decrease of dietary carbohydrate levels reduces glucose absorption and further affects lipid synthesis in juvenile ide.

In the present study, both plasma glucose and triglyceride levels decreased with increasing dietary protein (decreasing dietary starch) levels, which was in agreement with results in obscure puffer (Ye et al., 2017), and yellow croaker, Pseudosciaena Crocea (Yu et al., 2012).

Hematological parameters in the blood indicate the health status of fish (Tewary and Patra, 2011). In the present study, WBC, RBC, HGB, and HCT contents were independent of dietary protein levels. Similarly, another study found that dietary protein levels did not affect the RBC contents in obscure puffer (Ye et al. 2017). However, in blunt snout bream Megalobrama amblycephala, from our previous study, WBC content was not significantly affected by dietary protein levels, whereas RBC, HBG and HCT content was enhanced by increasing dietary protein levels (Habte-Tsion et al., 2013). AST activity is used as an indicator of liver function; high AST activity generally indicates weakened or damaged normal liver function in fish species (Kim and Lee, 2009). In the present study, the highest serum AST activity was observed in fish fed a diet with $26.5 \%$ protein; it was possibly affected by malnutrition as suggested by poor growth performance.

In conclusion, the present results indicate that dietary protein affects growth, feed utilization, whole-body composition, and plasma parameters in juvenile ide. The dietary protein requirement for this fish species was determined to be $36.9-37.7 \%$ of dry diet based on SGR and FCR, and the optimal dietary methionine and lysine was $0.83 \%$ and $2.25 \%$ of dry diet, respectively. However, dietary EAA, lipid, and other nutrient levels for optimal growth of ide needs to be investigated in the future.

\section{Acknowledgments}

This study was financially supported by the Modern Agriculture Industrial Technology System special project-the National Technology System for Conventional Freshwater Fish Industries (CARS-46).

\section{References}

Ahmad M.H., 2008. Response of African catfish, Clarias gariepinus, to different dietary protein and lipid levels in practical diets. J. World Aquac. Soc., 39: 541-548.

Ai Q.H., Mai K.S., Li H.T., Zhang C.X., Zhang L., Duan Q.Y., Tan B.P., Xu W., Ma H.M., Zhang W.B. and Z.G. Liufu, 2004. Effects of dietary protein to energy ratios on growth and body composition of juvenile Japanese seabass, Lateolabrax japonicas. Aquaculture, 230: 507-516.

AOAC, 2003. Official methods of analysis of the association of official analytical chemists 15th ed. Association of Official Analytical Chemists Inc. Arlington VA.

Bergot F., 1979. Carbohydrate in rainbow trout diets: effects of the level and source of carbohydrate and the number of meals on growth and body composition. Aquaculture, 18: 157-167.

Błachuta J., 1998. Function of native reophileous cyprinids in river ecosystems. Proceedings of Conference reophileous cyprinids, Brwinów 1998, SGGW, pp. 17-21, (in Polish).

Brauge C., Corraze G. and F. Médale, 1995. Effects of dietary levels of carbohydrates and lipid on glucose oxidation and lipogenesis from glucose in rainbow trout, Oncorhynchus mykiss, reared in freshwater or in seawater. Comp. Biochem. Physiol., 111A: 117-124.

Deng J., Kang B., Tao L., Bi B., Yang X., Long X., Han X. and X. Zhang, 2013. Dietary Protein Requirement for Juvenile Barbless Carp, Cyprinus pellegrini. Isr. J. Aquacult.-Bamidgeh, 65.2013.888. 
Deng J.M., Zhang X., Bi B.L., Kong L.F. and B. Kang, 2011. Dietary protein requirement of juvenile Asian red-tailed catfish Hemibagrus wyckioides. Animal Feed Science and Technology, 170: 231-238.

Gaye-Siessegger J., Focken U. and K.Becker, 2006. Effect of dietary protein/ carbohydrate ratio on activities of hepatic enzymes involved in the amino acid metabolism of Nile tilapia, Oreochromis niloticus (L.). Fish Physiol. Biochem., 32: 275282.

Giri S.S., Sahoo S.K., Paul B.N., Mohanty S.N. and A.K. Sahu, 2011. Effect of dietary protein levels on growth, feed utilization and carcass composition of endangered bagrid catfish Horabagrus brachysoma (Gunther 1864) fingerlings Aquacult. Nutr., 17: 332-337.

Habte-Tsion H.M., Liu B., Ge X.P., Xie J., Xu P., Ren M.C., Zhou Q.L., Pan L.K. and R. Chen R., 2013. Effects of dietary protein levels on the growth performance, muscle composition, blood composition and digestive enzymes activities of Wuchang bream, Megalobrama amblycephala fry. Israeli Journal of Aquaculture, 65: 1-9. Bamidgeh 2014 IJA_65. 925.

Kaushik S.J. and I. Seiliez, 2010. Protein and amino acid nutrition and metabolism in fish: current knowledge and future needs. Aquaculture Research, 41: 322-332.

Kim J.D. and S.P. Lall, 2001. Effects of dietary protein level on growth and utilization of protein and energy by juvenile haddock (Melanogrammus aeglefinus). Aquaculture, 195: 311-319.

Kim K.W., Wang X.J. and S.C. Bai, 2002. Optimum dietary protein level for maximum growth of juvenile olive flounder Paralichthys olivaceus (Temminck et Schlegel). Aquacult. Res., 33: 673-679.

Kim L.O. and S.M. Lee, 2005. Effects of the dietary protein and lipid levels on growth and body composition of bagrid catfish, Pseudobagrus fulvidraco. Aquaculture, 243: 323329.

Kim S.S. and K.J. Lee, 2009. Dietary protein requirement of juvenile tiger puffer (Takifugu rubripes). Aquaculture, 287: 219-222.

Luo Z., Liu Y.J., Mai K.S., Tian L.X., Liu D.H. and X.Y. Tan, 2004. Optimal dietary protein requirement of grouper Epinephelus coioides juveniles fed isoenergetic diets in floating net cages. Aquacult. Nutr., 10: 247-252.

Melo J.F.B., Lundstedt L.M., Metón I., Baanante I.V. and G. Moraes, 2006. Effects of dietary levels of protein on nitrogenous metabolism of Rhamdia quelen (Teleostei: Pimelodidae). Comp Biochem. Physiol., 145A: 181-187.

Mohanta K.N., Mohanty S.N. and J.K. Jena, 2007. Protein-sparing effect of carbohydrate in silver barb, Puntius gonionotus fry. Aquacult. Nutr., 4: 311-317.

Mohanta K.N., Mohanty S.N., Jena J.K. and N.P. Sahu, 2008. Protein requirement of silver barb, Puntius gonionotus fingerlings. Aquacult. Nutr., 14: 143-152.

Ng W.K., Soon S.C. and R. Hashim, 2001. The dietary protein requirement of a bagrid catfish, Mystus nemurus (Cuvier \& Valenciennes), determined using semipurified diets of varying protein level. Aquacult. Nutr., 7: 45-51.

Nose T., 1979. Summary report on the requirements of essential amino acids for carp. In: Halver, J.E., Tiews, K. (Eds.), Finfish Nutr. Fish feed Technol., Heinemann, Berlin. pp145-156.

NRC (National Research Council), 2011. Nutrient requirements of fish and shrimp. National Academy Press Washington D.C. pp 57-101.

Parazo M.M., 1990. Effects of dietary protein and energy level on growth, protein utilization and carcass composition of rabbitfish, Siganus guttatus. Aquaculture, 86: 4149.

Reitman S. and S. Frankel, 1957. Colorimetric determination of glutamic oxaloacetic and glutamic pyruvic transaminases. Am. J. Clin. Pathol., 28: 53-56.

Ren M.C., Habte-Tsion H.M., Xie J., Liu B., Zhou Q.L., Ge X.P., Pan L.K. and R.L. Chen, 2015. Effects of dietary carbohydrate source on growth performance, diet digestibility and liver glucose enzyme activity in blunt snout bream, Megalobrama amblycephala. Aquaculture, 438: 75-81.

Rohtla M., Svirgsden R., Taal I., Saks L., Eschbaum R. and M. Vetemaa, 2015. Life-history characteristics of ide Leuciscus idus in the Eastern Baltic Sea. Fish. Manag. Ecol., 22: 239-248. 
Tewary A. and B.C. Patra, 2011. Oral administration of baker's yeast (Saccharomyces cerevisiae) acts as a growth promoter and immunomodulator in Labeo rohita (Ham.). J. Aquacult. Res. Dev., 2: 1-7.

Tibbetts S.M., Lall S.P. and D.M. Anderson, 2000. Dietary protein requirement of juvenile American eel (Anguilla rostrata) fed practical diets. Aquaculture, 186: 145-155.

Webb K.A. and D.M. Gatlin, 2003. Effects of dietary protein level and form on production characteristics and ammonia excretion of red drum Sciaenops ocellatus. Aquaculture, 225: 17-26.

Yang S.D., Lin T.S., Liou C.H. and H.K. Peng, 2003. Influence of dietary protein levels on growth performance, carcass composition and liver lipid classes of juvenile Spinibarbus hollandi (Oshima). Aquacult. Res., 34: 661-666.

Ye C., Wu Y.L., Sun Z.Z. and A.L. Wang, 2017. Dietary protein requirement of juvenile obscure puffer, Takifugu obscurus. Aquaculture Research, 48: 2064-2073.

Yu H.R., Ai Q.H., Mai K.S., Ma H.M., Cahu C.L. and J.L.Z. Infante, 2012. Effects of dietary protein levels on the growth, survival, amylase and trypsin activities in large yellow croaker, Pseudosciaena Crocea R., larvae. Aquaculture Research, 43: 178-186.

Yun B., Yu X.T., Xue M., Liu Y., Wang J., Wu X.F., Han F. and X.F. Liang, 2015. Effects of dietary protein levels on the long-term growth response and fitting growth models of gibel carp (Carassius auratus gibelio). Animal Nutrition, 1: 70-76.

Zehra S. and M.A. Khan, 2012. Dietary protein requirement for fingerling Channa punctatus (Bloch), based on growth, feed conversion, protein retention and biochemical composition. Aquaculture International, 20: 383-395.

Zeitoun I.H., Ullrey D.E., Magee W.T., Gill J.L. and W.G. Bergen, 1976. Quantifying nutrient requirement of fish. Journal of Fisheries Research Board Canada, 33: 167-172.

Zhang J., Zhou F., Wang L., Shao Q. and Z. Xu, 2010. Dietary protein requirement of juvenile black sea bream, Sparus macrocephalus. J. World Aquac. Soc., 41: 151-164. 